\title{
Wheat agronomic parameters and water use efficiency under different bioclimatic stage in the North of Tunisia
}

\section{Belhaj Mguidiche Amel ${ }^{1}$, Douh Boutheina ${ }^{2}$ and Harbaoui Kalthoum $^{3}$}

${ }^{1}$ Olive Tree Institute of Tunisia. Email: amelmguidiche@yahoo.fr.

${ }^{2}$ Higher Institute of Agronomy of Chott Meriem. University of Sousse. Tunisia.

${ }^{3}$ Regional Field Crops Research Center (CRRGC). Béja. Tunisia.

\begin{abstract}
Improvement of water use efficiency (WUE) in wheat is important for almost all agricultural practices, so Water use efficiency (WUE), is the ratio of grain yield to crop water use, provides a simple means of assessing whether yield is limited by water supply or other factors. Limited precipitation restricts yield of wheat grown in Tunisia, so supplement irrigation will be paramount in Mediterranean agriculture in the future where wheat is a major crop. The present study was carried out in two stations of the Regional Filed Crop Research Center of Béja, Tunisia, in sub humid climatic stage and Oued Miliz in semi arid, in sub humid experiment was conducted rainfed whereas three irrigations levels were used in semi arid condition. The aim of this work was to study effect of biocliamtic stage and supplemental irrigation on yield and water use efficiency. There was a significant difference $(\mathrm{p}<0.05)$ in biological water use efficiency between two climatic stages for all varieties; whereas in the same condition there no significant difference between varieties.
\end{abstract}

Keywords: Bioclimatic stage; Water use efficiency; Supplemental irrigation.

\section{Introduction}

The most important consequences of climate change were its negative effect for the agricultural sector, economy, and a whole education in household incomes (Rosenzeig et al., 2004; Arnell et al., 2006; Alcamo et al., 2007; Iglesias and Garrote 2015). In
Received

June 25, 2018

Accepted

August 27, 2018

Released

August 31, 2018

Full Text Article

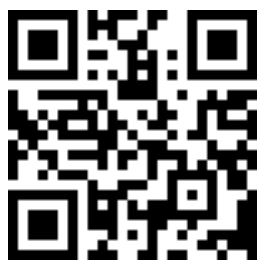

ORCID

(1) 0000-0002-2710-0146 Belhaj Mguidiche Amel

(1) 0000-0002-3439-2212

Douh Boutheina

(ㄷ) 0000-0001-5378-2024

Harbaoui Kalthoum
Tunisia, agriculture is the main consumer of available water resources (> 80\%) (Douh et al., 2013). Among all cultivated wheat, Triticum aestivum and Triticum durum are the most important cereal crops in the world and especially in Tunisia, which is a strategic sector. Indeed, cereal crop occupies one third of the cultivated area with 1.3 million ha in 
2013 (Onagri, 2015). The remaining area is cultivated with hexaploid bread wheat (Dalrymple, 1978). In Tunisia, wheat represent more than $70 \%$ of cereals and they correspond to $35 \%$ of arable land, Wheat production is a priority in Tunisia and its increase is politically encouraged to reach national self-sufficiency, Weeds represent a continuing problem in Tunisian cereal production and are one of the limiting growing factors (Gressel et al., 2004; Latiri et al., 2010). In arid and semi-arid areas, supplemental, and limited or deficit irrigation have been well studied and practiced for improving crop yield and increasing IWUE (Connor and Loomis 1991; Perrier and Salkini 1991; Li, 1993; English and Raja 1996; Oweis et al., 1998; Zhang et al., 1999; Wang et al., 2001; Kang et al., 2002). The interests of researchers and farmers in wheat production are focused on enhancing WUE on the basis of increasing crop yields, rather than enhancing WUE by simply limiting the irrigation.

This paper reports a study that tried to explore the effect of climatic stage and supplemental irrigation in semi arid area on yield component and water use efficiency for some wheat varieties.

\section{Materials and methods}

\section{Experiment field}

The experimental sites were located in Béja $\left(36^{\circ} 44^{\prime} 05^{\prime \prime} \mathrm{N}\right.$ and $9^{\circ} 13^{\prime}$ $\left.35^{\prime \prime} \mathrm{E}\right)$ and Oued Miliz ( $36^{\circ} 26^{\prime} 45^{\prime \prime} \mathrm{N}$ and $8^{\circ} 46^{\prime} 48.9^{\prime \prime}$ E) in the North of Tunisia. Table 1 present the pedoclimatic condition of two experimental sites.

Table 1. Pedoclimatic condition of two experimental sites.

\begin{tabular}{lcll}
\hline Experimental site & Bioclimatic stage & Soil type & pH \\
\hline Oued Beja & Sub humid & Clay loam & 7.2 \\
Oued Mliz & Semi arid & Clay loam & 7.4 \\
\hline
\end{tabular}

Experiment was conducted from December to June 2015-2016 at the Regional Field Crops Research Center. The climate is characterized as semi arid in the region of Oued Miliz and sub humid in the region of Béja. Béja experiment design was conducted rain fed $\left(\mathrm{I}_{\mathrm{b}}\right)$ according to a randomized complete block system with three replicates per treatment, divided into three blocks each with four varieties. Oued Miliz experiment design was a completely randomize block design divided into nine blocks each with four varieties (Figure 1).
Experiment consisted of three irrigation régimes (I0) rain fed, (It) full irrigated and (It/2) half irrigated. Daily weather data were recorded from a meteorological station installed in the experimental site Figure 2 and 3 present average temperatures for both experimental sites and monthly rainfall. Soils of the experimental areas are mostly clay loam. Gravimetric soil water content was determined at different depth, 0-20 cm, 20-40 cm and 40-60 cm. 


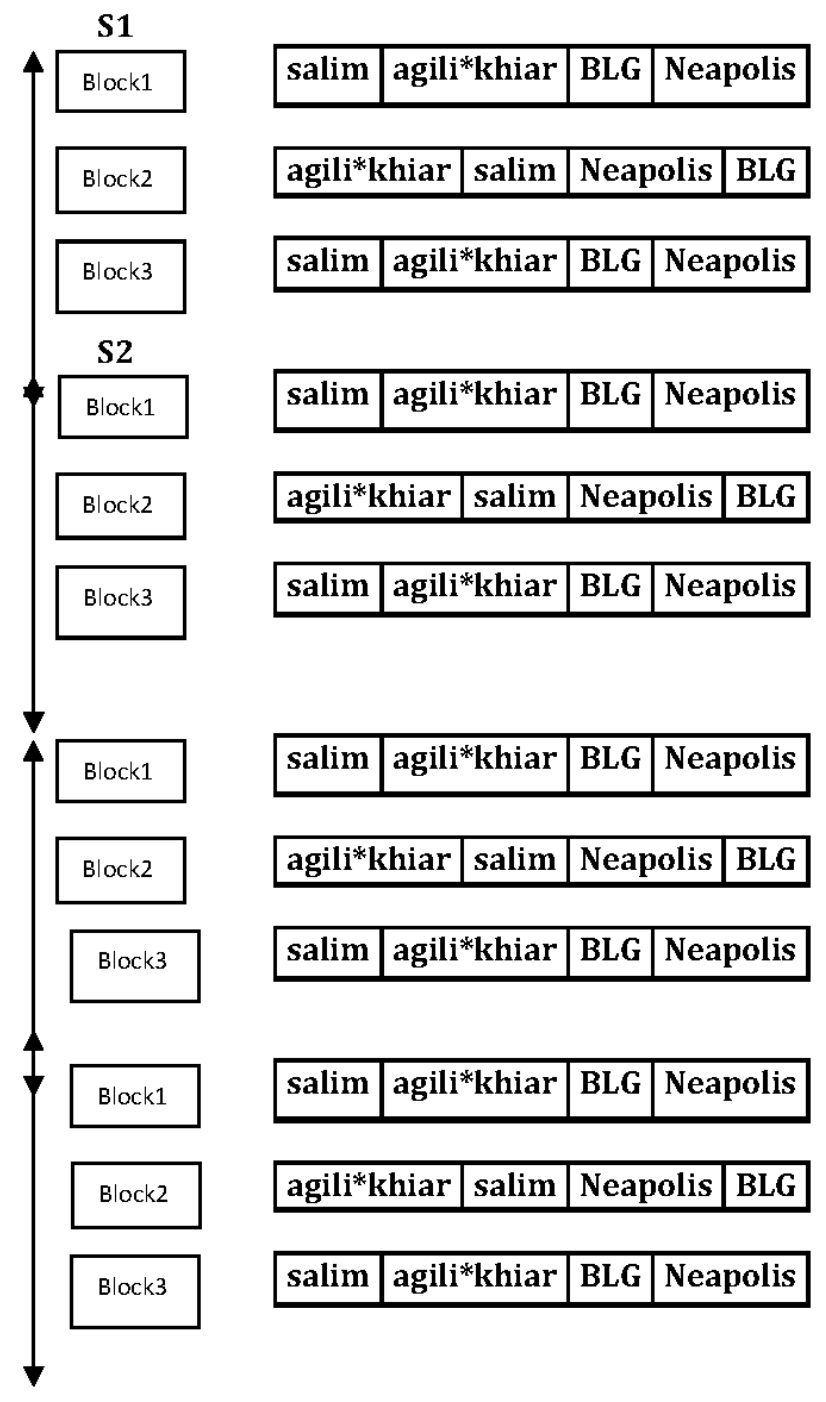

Figure 1. Parcel plan for both sites S1 sub humid and S2 semi arid condition.

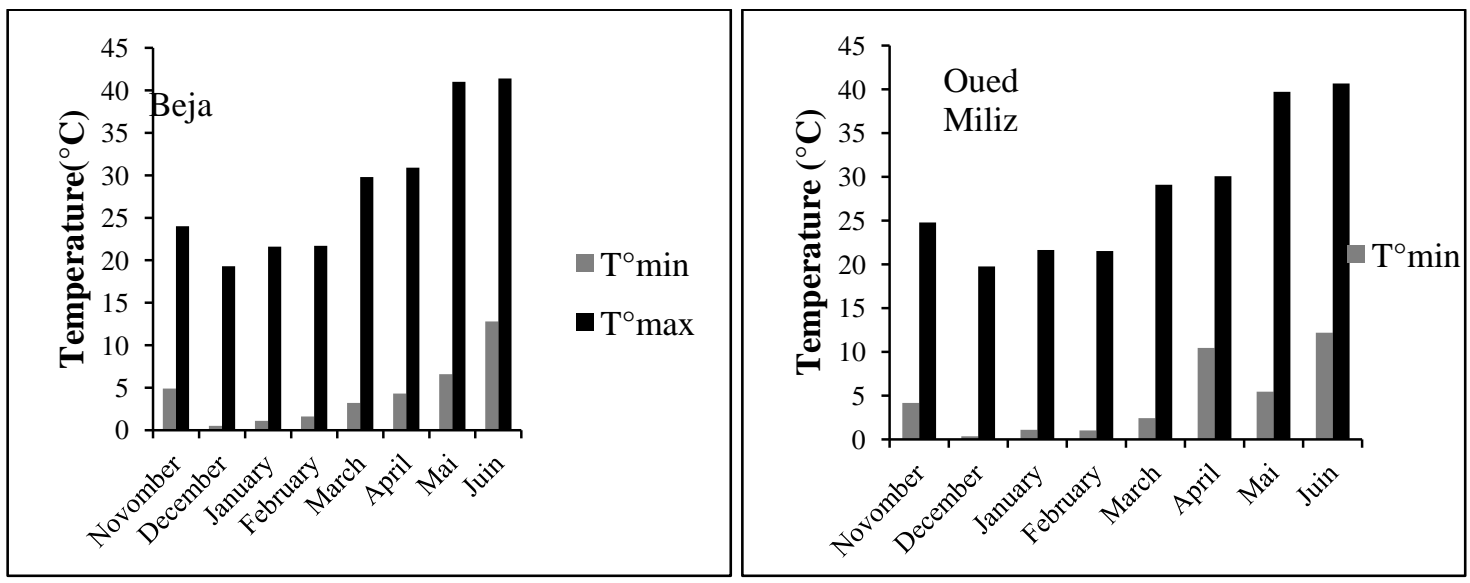

Figure 2. Average temperature for both experimental sites. 


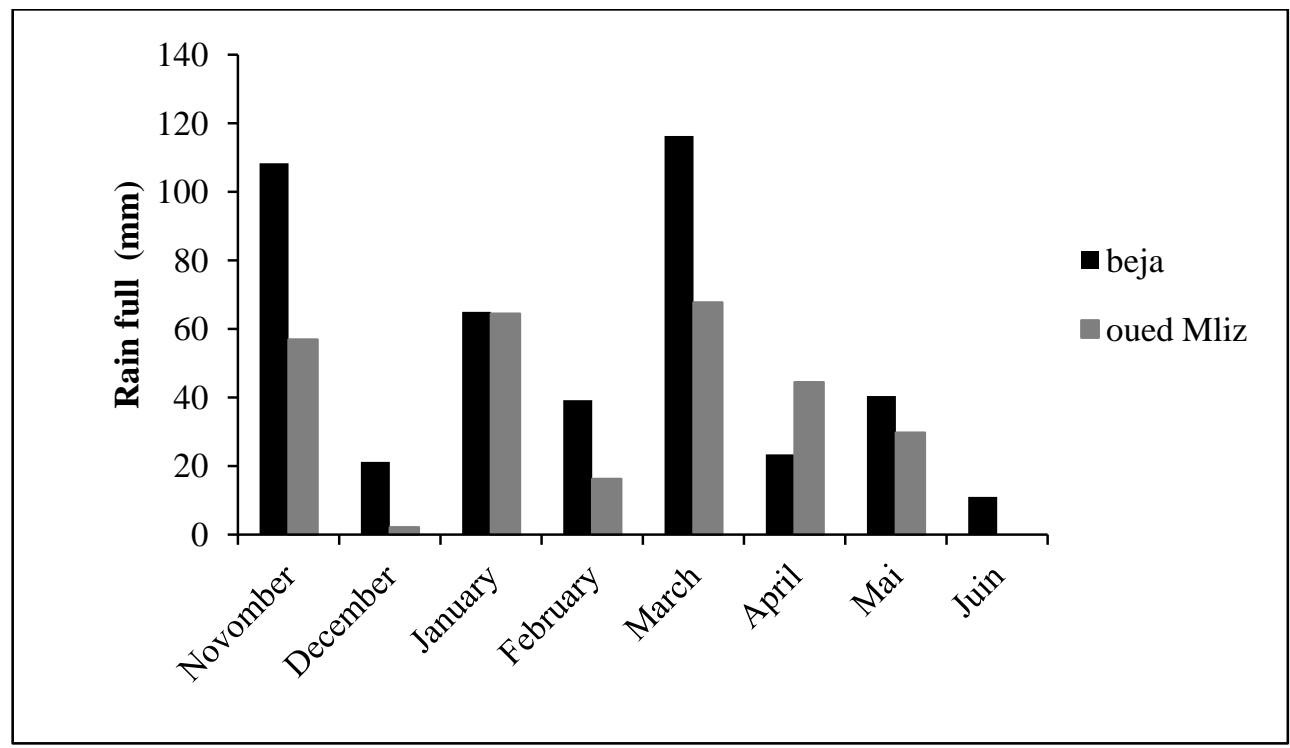

Figure 3. Monthly rainfall for both experiment sites.

\section{Crops}

Two varieties of durum wheat (Triticum turgidum subsp. durum Desf. (Poales: Poaceae)) Salim and Agili* Khiar, two of bread wheat (Triticum vulgare Vill. (Poales: Poaceae)) BLG and Neapolis were planted in this experiment.

\section{Methods}

At harvesting, for grain yield measurement one square meter were chosen at random in each plot. The number of spike per $\mathrm{m}^{2}$ was counted, before harvesting. The grains were sundried to a water content of about $10 \%$. Spike number per ears was estimated using kernel mass, ear number and grain yield per $\mathrm{m}^{2}$.

\section{Water use efficiency}

WUE was obtained by comparing the yield with respect to water consumption. It was calculated using biological yields (straw and grain) and grain yields. WUE is generally expressed in $\mathrm{kg} / \mathrm{ha} / \mathrm{mm}$ and defines the amount of production a unit of water used. Thus its unit can be converted into $\mathrm{kg} / \mathrm{m}^{3}$ $\left(1 \mathrm{~kg} / \mathrm{m}^{3}=10 \mathrm{~kg} / \mathrm{ha} / \mathrm{mm}\right)$ which is more easily perceived.

\section{Statistical analysis}

All data obtained from the effects of different irrigation regime and climatic condition treatments on plants yields were subjected to a statistical analysis using analysis of variance (ANOVA). The Least Significant Difference (LSD) at probability of $5 \%$ was performed to evaluate means using SPSS for windows.

\section{Results and discussions}

\section{Soil water content variation}

As we can show in Figure 4a soil water content was between $15 \%$ and $42 \%$ and decreases over time for all three depths with a pic in March 44.28\% where there was precipitation. Due to the severe climatic conditions and increased crop water requirements that enhance root extraction, soil water content decreases to $14 \%$ in all soil profiles at the end of the growing season. Figure $4 \mathrm{~b}$ shows that for all three depths soil water content variation is almost identical with a slight phase shift. Water content ranging from $8.1 \%$ to $17.9 \%$. The low values of the water content due to the increase of the root extraction and on the low water supply by rainfall. 

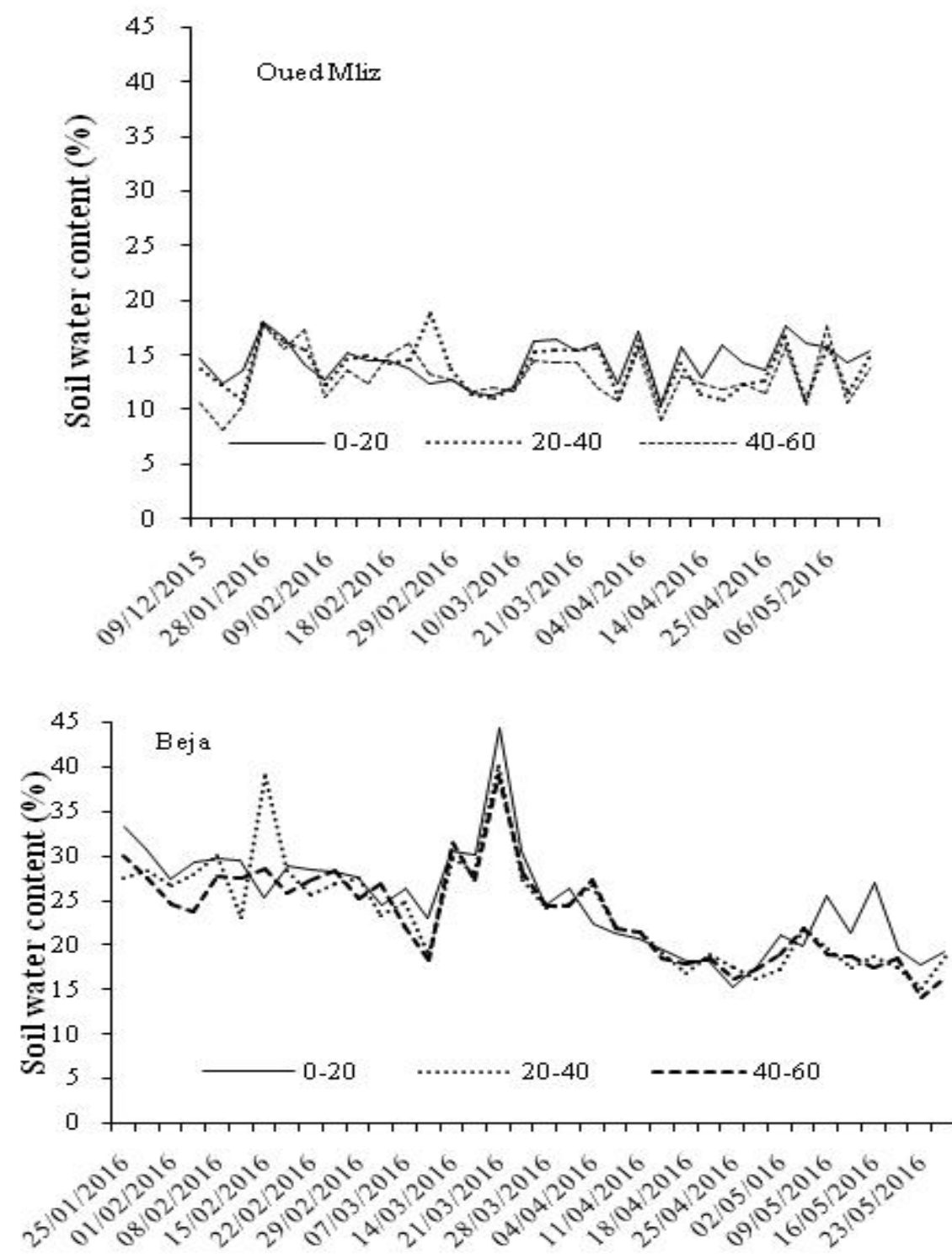

Figure 4. Soil water content variation $(0-60 \mathrm{~cm})$ for winter wheat in Oued Miliz (a) and Beja (b).

\section{Yield component under different climate condition \\ Available soil water stored at planting and precipitation during the entire growing season are the only sources of water supply for wheat production. Table 2 present yield component in sub humid and semi arid condition. According to bioclimatic stage the maximum grain yield and biomass value were recorded in sub humid}

condition for all varieties expected for Néapolis in semi arid condition with $272.5 \mathrm{~g} / \mathrm{m}^{2}$, the minimum total biomass was recorded in S2 with $0.41 \mathrm{~kg} / \mathrm{m}^{2}$ for agili* Khiar and the maximum in S2 with 1.25 for BLG. Statistical analysis shows that, there is a significant difference in biomass for all varieties between bioclimatic stage and no difference between the varieties in the same climatic stage. For grain yield there is no 
difference between the varieties for both climatic stage. Number spike were between 180 and $220 \mathrm{spike} / \mathrm{m}^{2}$ with no significant difference. The harvest indexes ranged from $0.21 \%$ to $0.4 \%$ with the highest value of $0.4 \%$ for Neapolis at semi arid climatic condition due to their much higher grain yields. Two linear functions were fitted through regression analysis among the data from grain yield and total biomass for both sites S1 and S2, grain yield increased linearly with harvest index and total biomass with $\mathrm{R}^{2}$ higher than 0.9 (Figure 5) and the increase in grain yield under two climatic condition was result of the increase in both total biomass and harvest index which were in line with data in Figure 6.

Table 2: Yield component under different climate condition.

\begin{tabular}{|c|c|c|c|c|c|c|}
\hline & & $\begin{array}{l}\text { Biomass } \\
\left(\mathrm{kg} / \mathrm{m}^{2}\right)\end{array}$ & $\begin{array}{l}\text { Grain Yield } \\
\qquad\left(\mathrm{g} / \mathrm{m}^{2}\right)\end{array}$ & $\begin{array}{c}\text { Harvest } \\
\text { index }\end{array}$ & $\begin{array}{l}\text { Number of } \\
\text { Spike/m² }\end{array}$ & $\begin{array}{l}\text { Weight of } \\
\text { thousand } \\
\text { grain (g) }\end{array}$ \\
\hline \multirow{4}{*}{$\begin{array}{l}\text { Beja } \\
\text { (S1) }\end{array}$} & Salim & $1.11^{\mathrm{a}, \mathrm{a}}$ & $250.03^{\mathrm{a}, \mathrm{a}}$ & $0.21^{\mathrm{b}, \mathrm{a}}$ & $220^{a, a}$ & $39.3^{\mathrm{a}, \mathrm{a}}$ \\
\hline & Agili*khiar & $1.14^{\mathrm{b}, \mathrm{a}}$ & $243.80^{\mathrm{a}, \mathrm{a}}$ & $0.20^{\mathrm{a}, \mathrm{a}}$ & $198^{a, a}$ & $38.5^{\mathrm{a}, \mathrm{a}}$ \\
\hline & BLG & $1.25^{\mathrm{a}, \mathrm{a}}$ & $313.02^{\mathrm{a}, \mathrm{a}}$ & $0.25^{\mathrm{a}, \mathrm{a}}$ & $222^{\mathrm{a}, \mathrm{a}}$ & $32.8^{\mathrm{a}, \mathrm{a}}$ \\
\hline & Neapolis & $1.23^{\mathrm{a}, \mathrm{a}}$ & $308.50^{\mathrm{a}, \mathrm{a}}$ & $0.24^{\mathrm{a}, \mathrm{a}}$ & $227 \mathrm{a}, \mathrm{a}$ & $31.1^{\mathrm{b}, \mathrm{a}}$ \\
\hline \multirow{4}{*}{$\begin{array}{l}\text { Oued Miliz } \\
\text { (S2) }\end{array}$} & Salim & $0.47^{\mathrm{a}, \mathrm{a}}$ & $123.70^{\mathrm{b}, \mathrm{a}}$ & $0.26^{\mathrm{a}, \mathrm{a}}$ & $180^{\mathrm{a}, \mathrm{a}}$ & $38.0^{\mathrm{a}, \mathrm{a}}$ \\
\hline & Agili*khiar & $0.41^{\mathrm{b}, \mathrm{a}}$ & $134.10^{\mathrm{b}, \mathrm{a}}$ & $0.32^{\mathrm{a}, \mathrm{a}}$ & $207^{\mathrm{a}, \mathrm{a}}$ & $35.7^{\mathrm{a}, \mathrm{a}}$ \\
\hline & $\mathrm{BLG}$ & $0.56^{\mathrm{b}, \mathrm{a}}$ & $211.60^{\mathrm{a}, \mathrm{a}}$ & $0.35^{\mathrm{a}, \mathrm{a}}$ & $205^{\mathrm{a}, \mathrm{a}}$ & $33.3^{\mathrm{a}, \mathrm{a}}$ \\
\hline & Neapolis & $0.68^{\mathrm{b}, \mathrm{a}}$ & $272.50^{\mathrm{a}, \mathrm{a}}$ & $0.40^{\mathrm{a}, \mathrm{a}}$ & $206^{\mathrm{a}, \mathrm{a}}$ & $39.0^{\mathrm{a}, \mathrm{b}}$ \\
\hline
\end{tabular}

\section{Biomass, Grain yield and Harvest index under different irrigation regimes}

Table 3 present yield components in semi arid condition under different irrigation level (Iot) full irrigated (Io/2) half irrigated and (I0) conducted rainfed. As we can show from the Table 3 generally there is no significant difference on biomass and grain yield in irrigation regime of all variety, the tree irrigated treatments indicate positive effects on grain yield. Such differences in grain yields may result from many reasons such as variety, soil, climate, crop management and agricultural techniques on improved practical measures such as enhancing seedling density, delaying sowing date, applying phosphorus fertilizer, etc, resulted in improved grain yield ( $\mathrm{Li}$ et al., 2000). Number of spike $/ \mathrm{m}^{2}$ was between 180 and $280 \mathrm{spike} / \mathrm{m}^{2}$ with a no significant difference so spike number don't affected by irrigation, all varieties receive the same rainfall and irrigation in the milking stage, weight of 1,000-grain was found to not differ significantly between the two cultivars, neither in response to supplemental irrigation Although, irrigating at milking stage amplified grain weight. These results were in agreement with previous studies done by Mogenson et al. (1985). 
Table 3. Yield component in semi arid condition under different irrigation level.

\begin{tabular}{|c|c|c|c|c|c|c|}
\hline & & $\begin{array}{l}\text { Biomass } \\
\left(\mathrm{kg} / \mathrm{m}^{2}\right)\end{array}$ & $\begin{array}{c}\text { G Grain yield } \\
\left(\mathrm{g} / \mathrm{m}^{2}\right)\end{array}$ & $\begin{array}{l}\text { Harvest } \\
\text { index }\end{array}$ & $\begin{array}{l}\text { Number of } \\
\text { spike } / \mathbf{m}^{2}\end{array}$ & $\begin{array}{l}\text { Weight of } \\
\text { thousand } \\
\text { grain (g) }\end{array}$ \\
\hline \multirow[t]{4}{*}{ 1Iot } & Salim & $0.72^{\mathrm{a}, \mathrm{a}}$ & $264.1^{\mathrm{a}, \mathrm{a}}$ & $0.35^{\mathrm{a}, \mathrm{a}}$ & $256^{\mathrm{a}, \mathrm{a}}$ & $47.56^{\mathrm{a}, \mathrm{a}}$ \\
\hline & Agili*khiar & $0.75^{\mathrm{a}, \mathrm{a}}$ & $280.0^{\mathrm{a}, \mathrm{a}}$ & $0.36^{\mathrm{a}, \mathrm{a}}$ & $285^{\mathrm{a}, \mathrm{a}}$ & $42.00^{\mathrm{a}, \mathrm{a}}$ \\
\hline & BLG & $0.68^{\mathrm{a}, \mathrm{a}}$ & $247.4^{\mathrm{a}, \mathrm{a}}$ & $0.36^{\mathrm{a}, \mathrm{a}}$ & $213^{\mathrm{a}, \mathrm{a}}$ & $40.20^{\mathrm{ab}, \mathrm{a}}$ \\
\hline & Neapolis & $0.74^{\mathrm{a}, \mathrm{a}}$ & $330.8^{a, a}$ & $0.47 \mathrm{a}, \mathrm{a}$ & $254^{\mathrm{a}, \mathrm{a}}$ & $40.60^{\mathrm{a}, \mathrm{a}}$ \\
\hline \multirow[t]{4}{*}{ Iot/2 } & Salim & $0.83^{\mathrm{b}, \mathrm{a}}$ & $265.0^{\mathrm{a}, \mathrm{a}}$ & $0.31^{\mathrm{ab}, \mathrm{a}}$ & $270^{\mathrm{a}, \mathrm{a}}$ & $47.90^{\mathrm{a}, \mathrm{a}}$ \\
\hline & Agili*khiar & $0.76^{\mathrm{b}, \mathrm{a}}$ & $257.4^{\mathrm{a}, \mathrm{a}}$ & $0.33^{\mathrm{a}, \mathrm{a}}$ & $266^{\mathrm{a}, \mathrm{a}}$ & $45.03^{\mathrm{a}, \mathrm{a}}$ \\
\hline & BLG & $0.91^{\mathrm{a}, \mathrm{a}}$ & $271.9^{\mathrm{a}, \mathrm{a}}$ & $0.47^{\mathrm{a}, \mathrm{a}}$ & $182^{\mathrm{a}, \mathrm{a}}$ & $42.60^{\mathrm{a}, \mathrm{a}}$ \\
\hline & Neapolis & $0.46^{\mathrm{a}, \mathrm{a}}$ & $222.3^{\mathrm{a}, \mathrm{a}}$ & $0.59^{\mathrm{a}, \mathrm{a}}$ & $176^{\mathrm{a}, \mathrm{a}}$ & $42.40^{\mathrm{a}, \mathrm{a}}$ \\
\hline \multirow[t]{4}{*}{ I0 } & Salim & $0.47^{\mathrm{a}, \mathrm{a}}$ & $123.0^{\mathrm{b}, \mathrm{a}}$ & $0.26^{\mathrm{b}, \mathrm{a}}$ & $180^{\mathrm{b}, \mathrm{a}}$ & $38.00^{\mathrm{b}, \mathrm{a}}$ \\
\hline & Agili*khiar & $0.41^{\mathrm{a}, \mathrm{a}}$ & $134.0^{\mathrm{b}, \mathrm{a}}$ & $0.32^{\mathrm{a}, \mathrm{a}}$ & $207^{b, a}$ & $35.70^{\mathrm{b}, \mathrm{a}}$ \\
\hline & BLG & $0.56^{\mathrm{a}, \mathrm{a}}$ & $211.5^{\mathrm{a}, \mathrm{a}}$ & $0.35^{\mathrm{a}, \mathrm{a}}$ & $205^{\mathrm{a}, \mathrm{a}}$ & $33.30^{\mathrm{b}, \mathrm{b}}$ \\
\hline & Neapolis & $0.68^{\mathrm{a}, \mathrm{a}}$ & $272.0^{\mathrm{a}, \mathrm{a}}$ & $0.40^{\mathrm{a}, \mathrm{a}}$ & $206^{\mathrm{a}, \mathrm{a}}$ & $39.90^{\mathrm{a}, \mathrm{a}}$ \\
\hline
\end{tabular}

\section{Water use efficiency under} différent climatic condition

Biological and grain water use efficiency for all varieties for both sub humid and semi arid climatic condition are presented in fig (7). Results of statistical analysis showed significant differences ( $p<$ 0.05 ) in biological water use efficiency between two climatic stages for all varieties but in the same condition there were no significant difference between varieties. For grain water use efficiency no significant difference for two varieties BLG and Neapolis and for salim and agili*Khiar there was significant difference between varieties under different climatic stage for all varieties biological or grain water use efficiency in sub humid are high and most important than in semi-arid climatic condition. Hagan et al. (1967) also asserted that excessive irrigation delays the maturity, harvesting and decreased grain yield; (Jin et al., 1999) reported that excessive irrigation led to decrease the WUE of the crop and that effective deficit irrigation may result in higher production and WUE. Figure 8 indicate four linear relations between grain WUE and harvest index grain yield in site S1 and S2. The linearly increased grain WUE was the consequence of increase in harvest and grain yield.

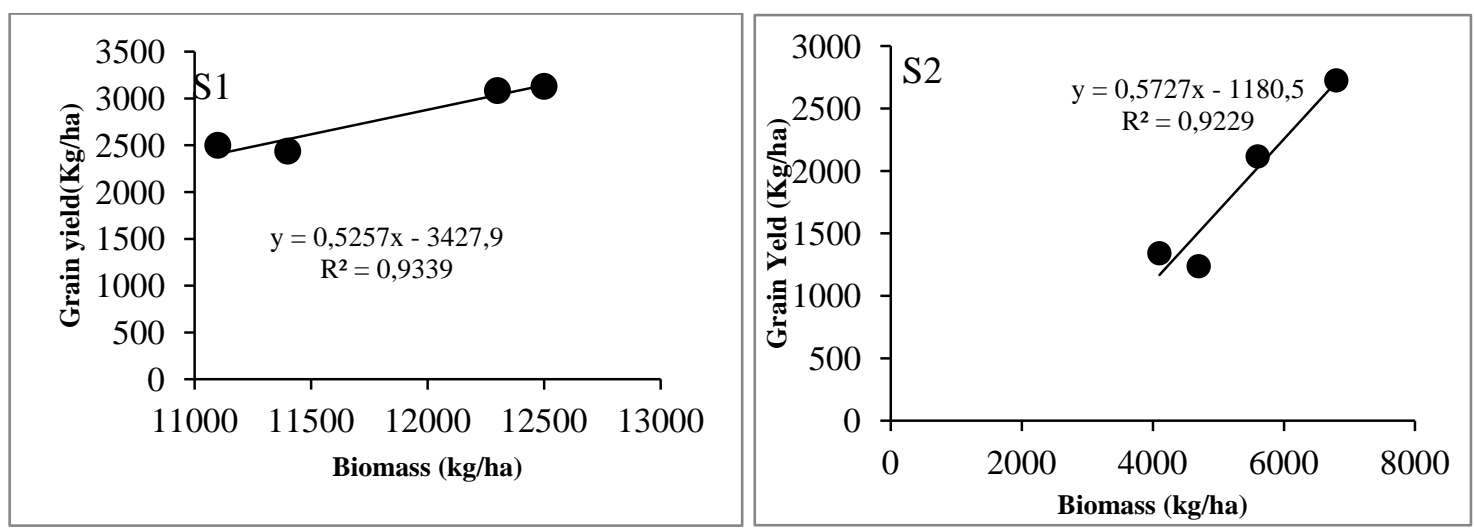

Figure 5. Relationship between grain yield and biomass for wheat for both sites (S1) and (S2). 

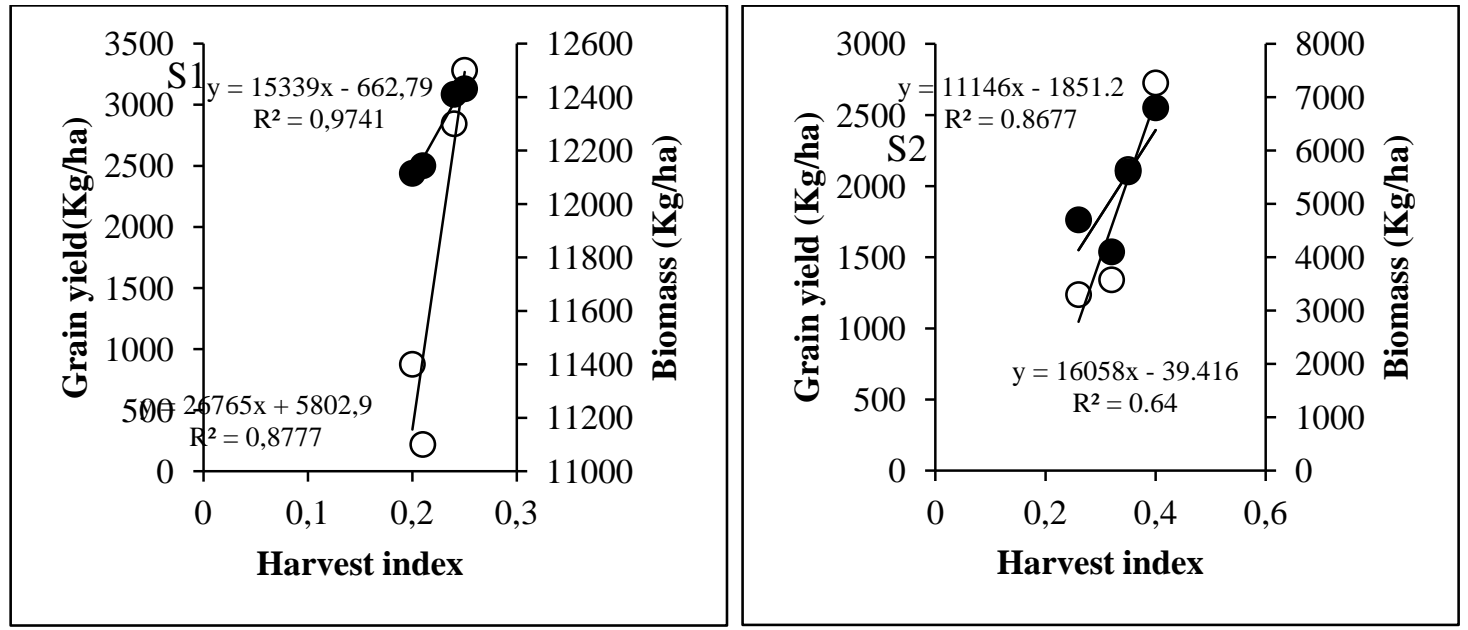

Figure 6. Relationships between harvest index and grain yield, biomass for wheat in both sites (S1) and (S2).
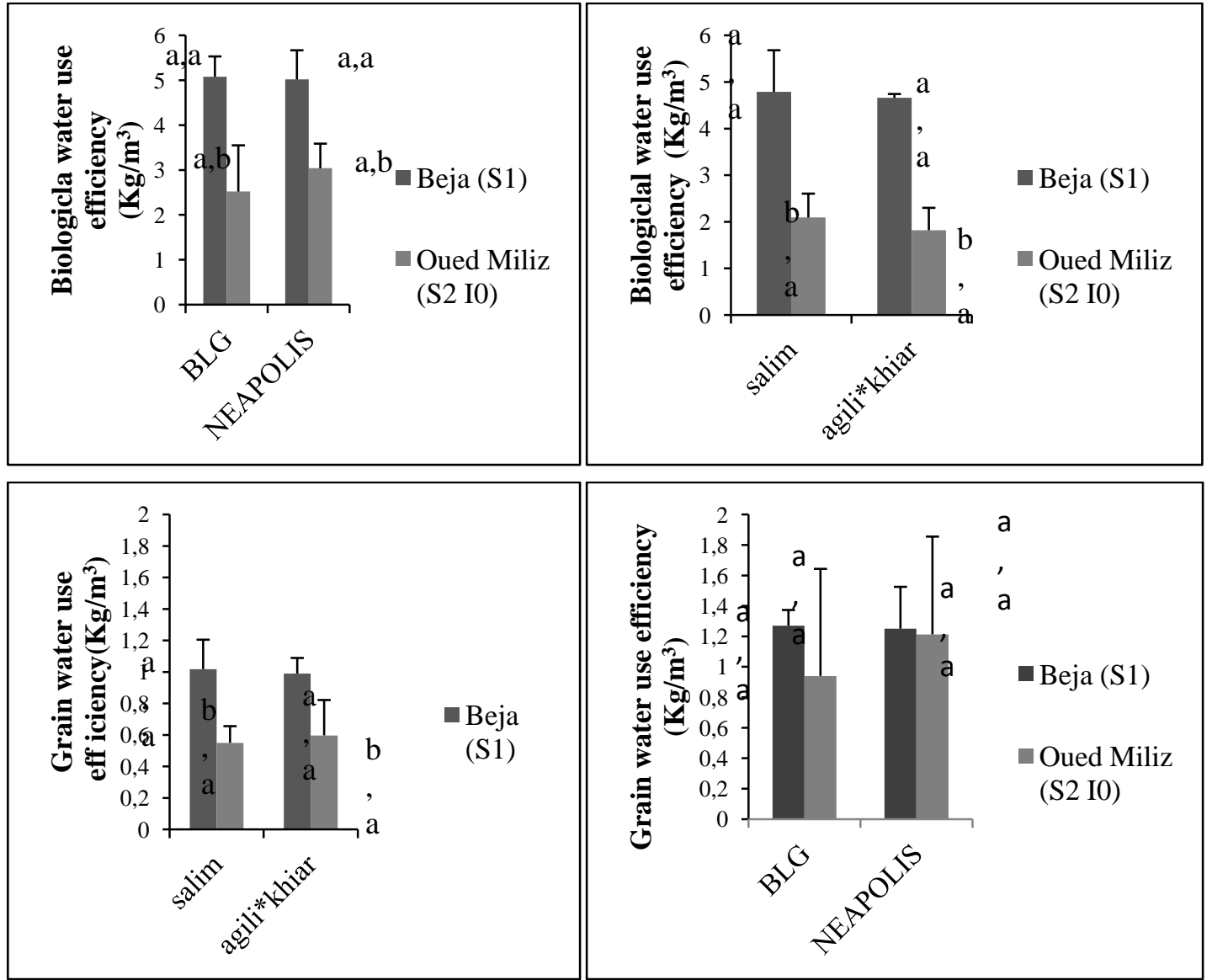

Figure 7. Biological and grain water use efficiency for wheat cultivars for both climatic stages. 


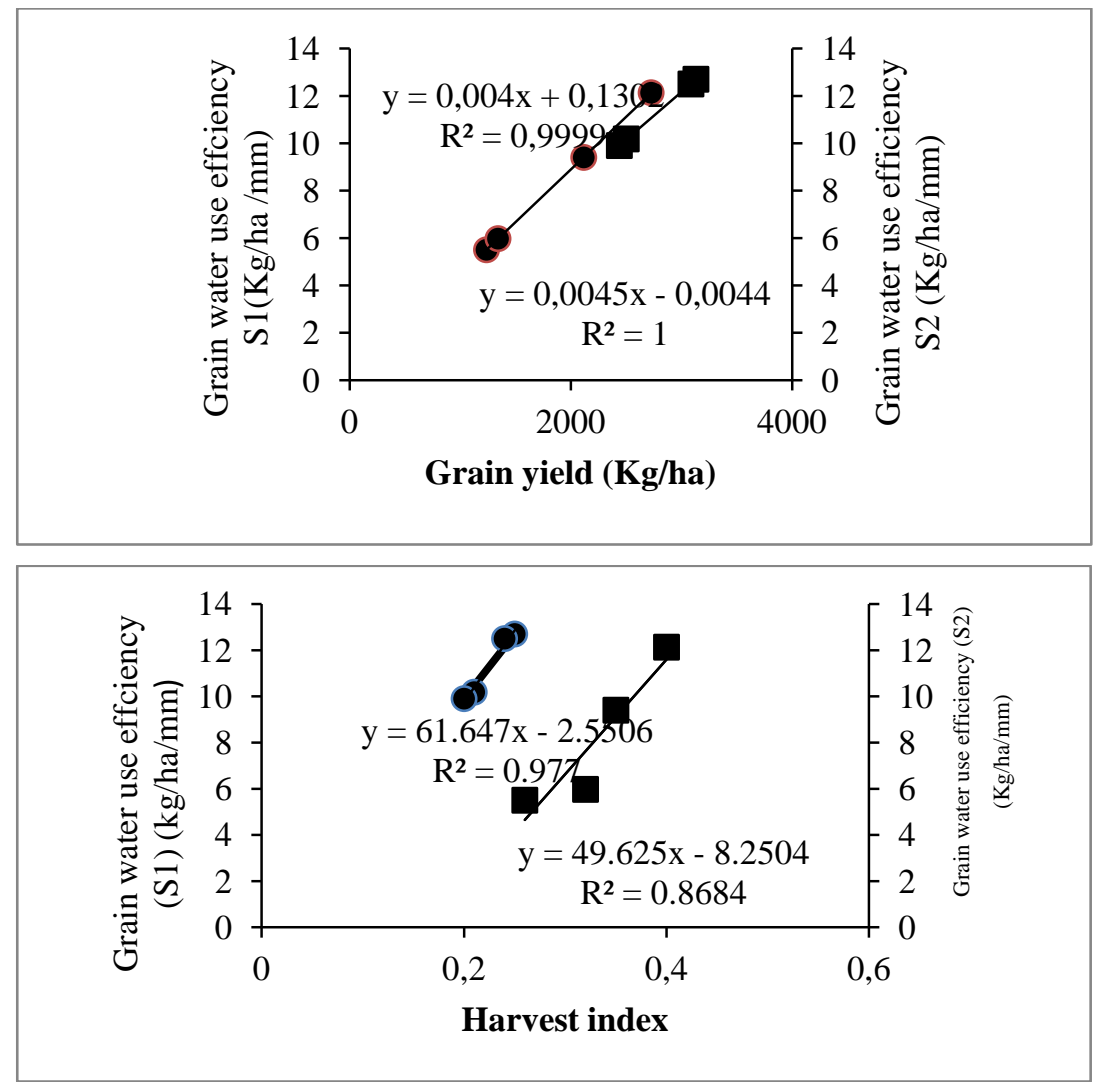

Figure 8. Relationships between water grain yield and grain water use efficiency for S1 and S2 and between harvest index and grain water use efficiency.

\section{Water use efficiency under different irrigation regime}

Grain and biological water use efficiency in semi arid condition under different irrigation level are presented in Figure 9, The results of statistical analysis indicated there were non significant differences $(p<0.05)$ for irrigation régime on biological water use efficiency for all varieties with generally low value on no irrigated cultivars for salim and agil*Khiar were about 2.38 and $2.48 \mathrm{~kg} / \mathrm{m}^{3}$. For grain water use efficiency no significant difference on irrigation regime for BLG and Néapolis varieties therefore a sigficant difference was observed is salim and agili* Khiar for no irrigated regime compared with the two irrigated régime with about 0.55 and
$0.5 \mathrm{~kg} / \mathrm{m}^{3}$ for salim and agili* Khiar. These results approved by other studies (Musick et al., 1994; Howell et al., 1995; Jones and Popham, 1997; Eck, 1988; Zhang et al., 1998; Wang et al., 2001; Sun et al., 2006; Xue et al., 2006), in a study conducted by $\mathrm{Li}$ et al. (2005) deficit irrigation had higher IWUE of 12.2-15.0 $\mathrm{kg} \mathrm{ha}^{-1} \mathrm{~mm}^{-1}$ compared to full irrigation, which was $4.70-9.50 \mathrm{~kg} \mathrm{ha}^{-1} \mathrm{~mm}^{-1}$. In current years, many studies about the effects of supplemental irrigation on WUE have shown that appropriate supplemental irrigation can amplify crop yield by improving soil water content and their WUE significantly (Ehdaie, 1995; HoWell et al., 1998; Li et al., 1999; Deng et al., 2002; Zhang et al., 2004). 

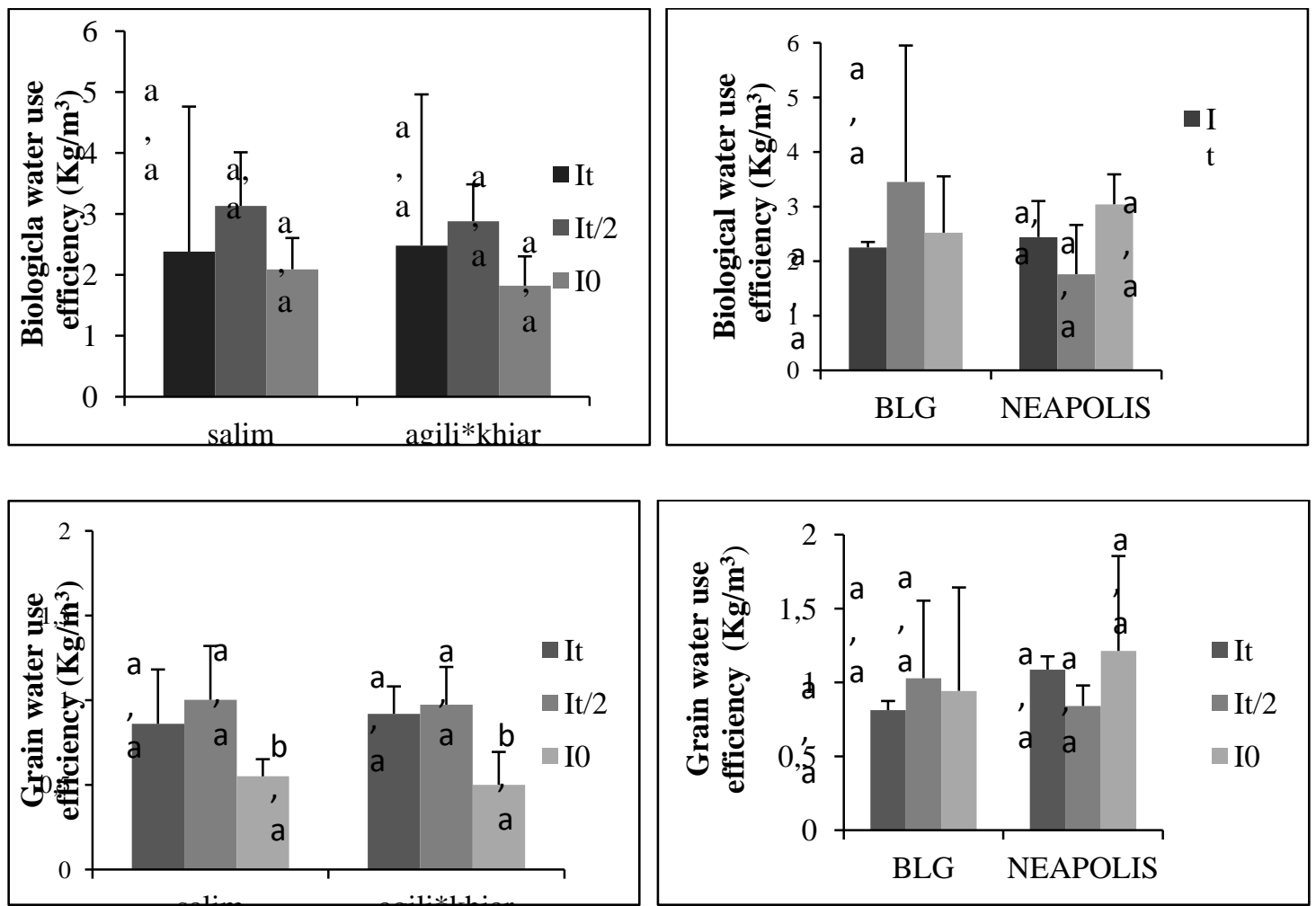

Figure 9. Biological and grain water use efficiency for wheat cultivars in different irrigation level.

\section{Conclusion}

Result show from this experiment that for rainfed plot for both climatic stage yield components were more important in sub humid area, also for biological and grain water use efficiency, there was linear relations between Grain water use efficiency and harvest index grain yield for both site S1 and S2. In semi arid area and half irrigated plot we show that irrigation increase yield components for biological and grain water use efficiency.

\section{Acknowledgements}

The authors gratefully acknowledge the support of personnel equip of regional field crop research center in Béja.

\section{Conflict of interest}

The authors declare that there are no conflicts of interest.

\section{References}

Alcamo, J.; Flörke, M.; Märker, M. Future longterm changes in global water resources driven by socio-economic and climatic changes. Hydrological Sciences Journal, $\begin{array}{lll}\text { v. } 52, \quad \text { no. } 2, & \text { p. 247-275, } 2007 .\end{array}$ https://doi.org/10.1623/hysj.52.2.247

Arnell, N.; Delaney, E. Adapting to climate change: public water supply in England and Wales. Climatic Change, v. 78 , no. $2 / 4$, p. 227-255, 2006. https://doi.org/10.1007/ s10584-006-9067-9

Baris, M. E.; Karadag, A. A. Water ressources managment issue in Turkey and recommendations. Journal of Applied Sciences, v. 7, no. 24, p. 3900-3908, 2007. https://doi.org/10.3923/jas.2007.3900.3908 
Byerlee, D. Wheat facts and trends. México City, México: Centro Internacional de Mejoramiento de Maíz y Trigo, 1981.

Connor, D. J.; Loomis, R. S. Strategies and tactics for water-limited agriculture in lowrainfall Mediterranean climates. Proceedings of the International Symposium on Improvement and Management of Winter Cereals under Temperature, Drought, and Salinity Stresses, Instituto Nacional de Investigaciones Agrarias, Madrid, Spain, $\mathrm{p}$ 441-465, 1991.

Cooper, P. J. M.; Gregory, P. J.; Tully, D.; Harris. H. C. Improving water use efficiency of annual crops in the rainfed farming systems of West Asia and North Africa. Experimental Agriculture, v. 23, p. 113-158, 1987. https://doi.org/10.1017/S00144797000169 4X

Dalrymple, D. G. Development and spread of high-yielding varieties wheat and rice in the less developed countries. Washington, DC: USDA Foreign Agricultural Economics, 1978. (Report No. 95). Available from: <https://ispc.cgiar.org/developmentand-spread-high-yielding-varieties-wheatand-rice-less-developed-nations $>$. Accessed on: Jan. 23, 2018.

Douh, B.; Boujelben, A.; Khila, S.; Bel Haj Mguidiche, A. Effect of subsurface drip irrigation system depth on soil water content distribution at different depths and different times after irrigation. Larhyss Journal, no. 13, p.7-16, 2013. Available from: <http://larhyss.net/ojs/index.php/larhyss/a rticle/view/152/145>. Accessed on: Jan. 23, 2018.

English, M.; Raja, S. N. Perspectives on deficit irrigation. Agric. Water Manage., v. 32, no. 1, p. 1-14, 1996. https://doi.org/10.1016/ S0378-3774(96)01255-3

FAO, 1990. Soil Map of the World. Paris: FAO-Unesco, 1996. v. 8.

Gregory, P. J.; Simmonds, L. P.; Pilbean, C. J. Soil type, climatic regime, and the response of water use efficiency to crop management. Agronomy Journal, v. 92, p. 814-820, 2000.

IWC - International Wheat Council. The world durum wheat situation. London: The Council, 1982. (Secretariat Paper 12).

Kang, S.; Zhang, L.; Liang, Y.; Hu, X.; Cai, H.; $\mathrm{Gu}, \mathrm{B}$. Effects of limited irrigation on yield and water use efficiency of winter wheat in the Loess Plateau of China. Agric. Water Manage., v. 55, p. 203-216, 2002.
Latiri, K.; Lhomme, P.; Annabi, M.; Setter, T. Wheat production in Tunisia: Progress, interannual variability and relation to rainfall. Eur. J. Agron., v. 33, p. 33-42, 2010.

Li, J.; Inanaga, S.; Li, Z.; Eneji, A. E. Optimizing irrigation scheduling for winter wheat in the North China Plain. Agric. Water Manag., v. 76, p. 8-23, 2005.

Li, J.; Zhou, D.; Wang, P.; Lan, M. The principals of winter wheat cultivation for high use efficiencies of water and fertilizers. Beijing, China: Publishing House of China Agricultural University, 2000. (In Chinese).

Li, Y. The Northern China needs a watersaving agriculture. Irrig. Drain., v. 12, p. 1020, 1999. (In Chinese)

Manoliadis, O. G. Analysis of irrigation systems using sustainability-related criteria. J. Environ. Qual., v. 30, p. 1150-1153, 2001.

Mogensen, V. O.; Jensen, H. E.; Rab, M. A. Grain yield, yield components, drought sensitivity and water use efficiency of spring wheat subjected to water stress at various growth stages. Irrig. Sci., v. 6, p. 131-140, 1985. https://doi.org/10.1007/BF00251561

ONAGRI - Observation Nationale de l'Agriculture. 2015. Available from: <http:/www.onagri.nat.tn>. Accessed on: Feb. 25, 2015.

Oweis, T. Y.; Pala, M.; Ryan, J. Stabilizing rainfed wheat yields with supplemental irrigation and nitrogen in a Mediterraneantype climate. Agron. J., v. 90, p. 672-681, 1998.

Perrier, E. R.; Salkini, A. B. Supplemental irrigation in the Near East and North Africa. Dordrecht, The Netherlands: Kluwer Academic Publisher, 1991.

Rosenzweig, C.; Strzepek, K.; Major, D.; Iglesias, A.; Yates, D.; Holt, A.; Hillel, D. Water availability for agriculture under climate change: Five international studies. Glob. Environ. Change, v. 14, p. 345-360, 2004.

Srivastava, J. P. Durum wheat: its world status and potential in the Middle East and North Africa. Rachis, v. 3, p. 1-8, 1984.

Wang, H.; Zhang, L.; Dawes, W. R.; Liu, C. Improving water use efficiency of irrigated crops in the North China Plain: measurements and modeling. Agric. Water Manage., v. 48, p. 151-167, 2001.

Zhang, H.; Wang, X.; You, M.; Liu, C. Wateryield relations and water use efficiency of 
winter wheat in the North China Plain. Irrig. Sci., v. 19, p. 37-45, 1999.

Zwart, S. J.; Bastiaansen, W. G. M. Review of measured crop water productivity values for irrigated wheat, rice, cotton and maize. Agricultural Water Management Journal, v. 69, p. 115-133. 2004.

License information: This is an open-access article distributed under the terms of the Creative Commons Attribution License, which permits unrestricted use, distribution, and reproduction in any medium, provided the original work is properly cited. 